DOI https://doi.org/10.36059/978-966-397-113-1/121-142

\title{
CORRUPTION AS A THREAT FOR CRITICAL INFRASTRUCTURE OBJECTS
}

\section{Dorokhina Yu. A.}

The guarantee of safety and resistance of national critical infrastructure is a priority direction of security policy in Ukraine, since critical infrastructure provides vital options for people, society and state without which it is impossible to exist safely and provide the proper level of national security.

Critical information infrastructure is considered as a main component in the critical infrastructure of many states reflecting in relevant approaches to such concept determination. The main reasons for the criticality of the infrastructure information component arise from the rapid spread of information technology in all domains of our life and, accordingly, the growth of vulnerabilities and potential threats of different nature. It is obvious that under such conditions, the security of cyber technologies in critical infrastructures (public management infrastructure, financial, banking, transport, energy, resource, communal and product supply) of modern society becomes one of the main issues.

The European Union defines critical infrastructure as a system that is essential for maintaining vital social functions. Damage to the critical infrastructure, its destruction or disturbance as a result of natural disasters, terrorism, criminal activity or abusive behavior may have a significant negative effect on the EU security and the well-being of citizens (European Council Directive 2008/114 / EC of 8 December 2008 on the identification and designation of European critical infrastructures and the assessment of the need to improve their protection).

At the present stage, the development of a critical infrastructure protection system at the national level is ensured by gradual steps taken by the Government of our country to develop an optimal state system for protecting critical infrastructure of Ukraine. Thus, the Government has adopted the Concept for the creation of a state system of protection of critical infrastructure of our state (hereinafter - the Concept), which was developed by the Ministry of Economic Development and Trade together 
with the National Institute of Strategic Studies and the Security Service of Ukraine. We should recall that the Concept was approved on December 6, 2017 by the Order № 1009-r of the Cabinet of Ministers of Ukraine.

The concept is the basis for the creation of a state system of protection of critical infrastructure objects, the violation of whose work may be harmful to the national interests of Ukraine. It defines all key concepts and proposes a mechanism for interaction between government bodies. The Government believes that the creation of such protection system will ensure the resilience to threats of all kinds. Thus, the Concept establishes a qualitatively new level of public management in this area and provides modern approaches to managing security risks, optimized use of available resources, flexibility and speed of response to incidents and crises.

The critical infrastructure objects include enterprises and institutions that are strategically important for the functioning of economy and security of the state, society and population, disruption or destruction of which could have an impact on national security and defense, natural environment, lead to significant material and financial losses, human victims. The term of "critical infrastructure" is used in such meaning as objects, systems and resources, physical or virtual, providing functions and services whose violation will lead to the most serious negative consequences for the life of population, society, socio-economic development, state defense and provision of national security.

The next step in creating a critical infrastructure protection system is the development and consideration of the draft law "On critical infrastructure and its protection", to be defined by the state bodies responsible for ensuring the implementation of measures on priority sectors of critical infrastructure, including the telecommunication and communication sector.

It is also essential to strengthen international cooperation in the field of critical infrastructure protection, which, together with the strengthening of the ability of national governments to provide protection for critical infrastructure, draws attention to the resolution of the UN Security Council in relation to critical infrastructure protection from terrorist attacks № 2341 on February 13, 2017.

It is believed that under the present conditions, the provision of security of the information field is on the first place in relation to the 
development of a high quality system of critical information infrastructure protection for our state, namely, cyber-security. In this regard, on October 5, 2017, the Verkhovna Rada of Ukraine adopted the Law "On the Basic Principles of Cyber-security Provision of Ukraine", which will come into force in six months after its publication. The said Law is an innovative document, since it establishes many important definitions at the legislative level: cyber-threat, cyber-espionage, cyber-crime, cyber-attack, as well as defines the necessity for a unified (universal) system of cyber-threats indicators, taking into account international standards on cyber-security and cyber-protection.

The law provides that enterprises and institutions that operate and provide services in the fields of chemical industry, energy, transport, ICT, banking and financial sectors, electronic communications; provide services in the field of life support of population; are utilities, emergency and rescue services; are included in the list of enterprises of strategic importance for the economy can be classified as the critical infrastructure objects.

This legal act opens new opportunities for settlement of situation in the information field. Despite the long discussions and the fears of certain experts regarding the possibility of excessive state control in the cyberfield, this Law will enable moving the development of the national information space to a qualitatively new level in the future ${ }^{1}$.

The task of protecting critical infrastructure moves the focus of attention to prevention of crisis situations in relation to its operation. In this regard, it should be emphasized that it is absolutely reasonable to add the anti-corruption system to existing systems of countermeasures.

It is believed that the protection of critical information infrastructure is not just an update of the terms in the current legislation; it is the introduction of a new approach. Its main components are the creation of a security partnership between all stakeholders, the organization of a comprehensive evaluation of threats to such infrastructure and their impact on the level of national security in its separate components, in particular the establishment of a mechanism for monitoring and preventing corruption offences.

\footnotetext{
${ }^{1}$ Рудь І. Закон про кібербезпеку: основні положення, оцінки експертів та розвиток вітчизняного інформаційного простору [Електронний ресурс] / І. Рудь // Україна: події, факти, коментарі. - 2017. № 19. - С. 42-48. - Режим доступу: http://nbuviap.gov.ua/images/ukraine/2017/ukr19.pdf.
} 


\section{Corruption as a Problem of a Modern Society}

The fight against corruption is a priority of Ukrainian society, and the spread of corruption to this day is one of the main real and potential threats to the national security of Ukraine, and its elimination is a priority task of the state authorities.

Corruption in Ukraine has an endemic nature, which is confirmed, including by the results of the study of Transparency International organization launched in 1998 in relation to Ukraine. According to the data of a non-governmental organization, over the last ten years Ukraine took the following place concerning the level of corruption: in 2007 $118^{\text {th }}$ place from 180 countries; in $2008-134^{\text {th }}$ place from 180 countries; in $2009-158^{\text {th }}$ place from 190 countries of the world; in $2010-$ $134^{\text {th }}$ place among 178 countries covered by the index; in $2011-152$ from 183 countries covered by research; in $2012-144^{\text {th }}$ place from 176 countries; in $2013-144^{\text {th }}$ place from 177 states; in $2014-142$ place from 175 positions; in $2015-130^{\text {th }}$ place out of 168 positions; in $2016-$ $131^{\text {st }}$ out of 176 countries and the following years are no exception.

The current study emphasizes that corruption remains one of the negative social phenomena disturbing Ukrainian society. In particular, if one turn to the population survey carried out by the Democratic Initiatives Foundation, how successful is the fight against corruption in Ukraine, more than $80 \%$ of respondents believe that it is not successful and only $1 \%$ of the population sees positive changes ${ }^{2}$.

Certainly, one can not say that there are no positive changes in the state. In particular, only during 2017 the Verkhovna Rada adopted about 50 bills that allow the introduction or continuation of key reforms of: the civil service, the judicial system, pension, educational, medical, etc. In particular, the reform of the judicial system has continued, namely: in January 2018 the new Supreme Court will work in full, there will be changes in appellate and local courts, which will also be certified and renewed in relation to judicial staff. The establishment of the Supreme Court on Intellectual Property and the Anticorruption Court is in the plans as well. All planned reforms should affect the level of corruption, and, accordingly, the easiness of doing business in Ukraine and its investment attractiveness.

\footnotetext{
2 Фонд «Демократичні ініціативи» [Електронний ресурс] - Режим доступу : http://dif.org.ua/ category/opinion-polls.
} 
That is why it can be stated that corruption is the stone that lies on the path the development of Ukraine. If we do not win, all the reforms will be useless, and Ukraine will not realize the potential that it has.

At the present stage, the country faces a range of specific problems, including the concentration of political and economic power in a small group of people who may hinder the implementation of effective anticorruption measures. This opinion is proved by the survey conducted by the National Agency for the Prevention of Corruption (hereinafterNAPC), "Corruption in Ukraine 2017". Thus, Ukrainians consider state institutions, courts, the Verkhovna Rada, the public prosecution office and the customs as having "sticky fingers" to the most. However, the corruption is known only to $59.4 \%$ of the population and $61.7 \%$ of entrepreneurs. At that, only $28.8 \%$ of ordinary Ukrainians and $42 \%$ of business representatives were able to name the anti-corruption bodies, and no more than $22-23 \%$ of all respondents were informed about their work results.

There are some interesting ideas from ordinary Ukrainians about corruption temptations. For example, if the patient paid 5 thousand UAH upon the doctor's request after surgery, $93.1 \%$ called it a bribe, but if the patient did the same, but on his free will - the act was disapproved only by $60.1 \%$. The situation, where a pensioner gives a postman $20 \mathrm{UAH}$, when a postman brings her a pension, only $33.5 \%$ of Ukrainians consider corruption. However, if the schoolteacher insists on additional paid lessons for the child, 58\% see it as unlawful benefit. Among the business representatives, $84.2 \%$ of respondents believe that if the director of the company hires an accountant on the condition of "gratitude" - this is also corruption.

The study also showed that ordinary Ukrainians are more tolerant to corruption than business representatives. Only $14.7 \%$ of people want to reveal the corruptor (among businessmen, such number is 24.7\%). Another $26 \%$ are ready to pay the necessary bribe (among entrepreneurs such number is $20.9 \%$ ). Instead, business representatives are more neutral about corruption $(53.8 \%)$ and use ties to solve problems $(22.4 \%)$. However, only $19 \%$ of the respondents wanted to report it when the real request for unlawful benefit took place. Of these, $7 \%$ reported and do not regret it, 3\% - feel sorry, $84 \%$ - kept silent. For reasons of refusal, $45 \%$ answered that they questioned the effectiveness of punishment, $32 \%-$ do 
not trust anti-corruption bodies, $19 \%$ - justify corruption. At the same time, 52\% consider the accused to be respectable people, $11.9 \%-$ careerists, $3.3 \%$ - strange, $9.6 \%$ - jealous, $7.7 \%$ - greedy, $7.4 \%-$ traitors ${ }^{3}$.

Regarding positive trends, the study showed that both businessmen and ordinary Ukrainians believe that the highest results in the fight against corruption are demonstrated by mass media representatives, public organizations, anti-corruption authorities, namely: the National AntiCorruption Bureau of Ukraine (hereinafter - NABU), the Specialized anticorruption prosecution office (hereinafter - SAP), NAPC, National Police, etc.

In the field of counteracting to corruption, significant human, material and financial resources are involved. In particular, according to UNIAN, on September 16, 2016, the European Commissioner for Enlargement and European Neighborhood Policy Johannes Hahn said that the European Union allocated more than 16 million euros in support of Ukrainian state anti-corruption bodies ${ }^{4}$.

In the autumn of 2017, World Bank President Jim Yong Kim pointed out that the newly formed Ukrainian anti-corruption authorities already have achievements in revealing and fighting corruption, and these bodies need support, including financial support, for the further implementation of anti-corruption reforms in Ukraine. In particular, the press service of NABU reminded that during his last visit to Ukraine in November 2017, Jim Yong Kim noted that the support would be aimed at helping to create an Anti-corruption court, and would include consultations, training and potential strengthening. Thus, material assistance will come in the form of IT equipment and software. The total budget of the program is 16.34 million euros, where the European Union contribution makes 15 million euros, and the rest amount is from Denmark ${ }^{5}$.

One of the most important steps in fulfillment of international commitments in Ukraine in the field of counteraction against corruption was the adoption of some normative legal acts on anticorruption, including the Law of Ukraine "On the Principles of State Anti-Corruption

\footnotetext{
3 Фонд «Демократичні ініціативи» [Електронний ресурс] - Режим доступу : http://dif.org.ua/ category/opinion-polls.

4 ЄС виділяє 16 мільйонів євро на боротьбу з корупцією в Україні / Економічна правда // [Електронний ресурс] - Режим доступу : http://www.epravda.com. ua/news/2016/09/16/605743/.

5 ЄС і Данія виділили €16 млн на боротьбу 3 корупцією в Україні. - Режим доступу : http://ukr.lb.ua/news/2016/09/15/345242_ies_i_daniya_vidilili_16_mln_borotbu.html.
} 
Policy in Ukraine for 2014-2017" by the Verkhovna Rada of Ukraine on October 14, 2014» ${ }^{6}$, by which Anticorruption Strategy for 2014-2017 was approved. In fact, this Law and Strategy have changed the National AntiCorruption Strategy for 2011-2015, approved by the Decree of the President of Ukraine on October 21, 2011 ${ }^{7}$.

The Law of Ukraine "On the Principles of State Anti-Corruption Policy (Anticorruption Strategy 2014-2017)" provided for the transfer of significant material and personnel resources to fight with corruption. In recent years, the necessary expenses from the state budget of Ukraine provided for the creation of a new system of state specialized anticorruption bodies. At present, NAPC, NABU, SAP, the National Agency of Ukraine for the Detection, Investigation and Management of Assets Received from Corruption and Other Crimes (hereinafter - NARMA), the National Bureau of Investigations (hereinafter referred to as - NBI) are considered as key elements to overcome corruption by the public and international partners of Ukraine. At the same time, it is necessary to strengthen people's trust to them and their ability to counteract to corruption.

On September 8, 2017 Nataliia Korchak, chairman of NAPC, presented the concept of a new Anticorruption Strategy for 2018-2020 (hereinafter referred to as Strategy). Among the priority objectives of the project are: corruption level assessment and analysis of the results of the previous Anticorruption Strategy for 2014-2017, completion of the formation of anticorruption bodies, improvement of legislative initiative, prevention of corruption at all levels of power and in the private sector, etc.

In particular, the draft Strategy emphasizes that the elimination of corruption in the country in general and the struggle against its manifestations in certain fields of the economy and public management depend on the introduction of strong rules of good faith, observance of the rules of fair and transparent elections, and the level of democracy of a political system. Thus, the published results of the electronic declaration of incomes have shown not rare cases of possession of property and funds that do not correspond to their incomes and violate standards of good faith

\footnotetext{
6 Засади державної антикорупційної політики в Україні (Антикорупційна стратегія) на 20142017 роки, затв. Законом України від 14 жовтня 2014 року № 1699-VII [Електронний ресурс]. - Режим доступу: http://zakon2.rada.gov.ua/ laws/show/1699-18.

${ }^{7}$ Національна антикорупційна стратегія на 2011-2015 роки, затв. Указом Президента України від 21 жовтня 2011 року № 1001/2011 [Електронний pecypc]. - Режим доступу: http://zakon2.rada.gov.ua/ laws/show/1001/2011.
} 
by people's deputies of Ukraine. At the same time, parliamentary immunity complicates the mechanism of bringing such persons to criminal liability ${ }^{8}$.

In view of the abovementioned, it is worth emphasizing that today Ukraine has not carried out a review of legislation in order to ensure transparent, effective procedures for deprivation of deputies' immunity, provided that there are proper legal grounds for this, as well as the issue of possible limiting the parliamentary immunity to a certain extent is not considered, in particular, by introducing a functional immunity that would allow the deputy of Ukraine to be detained without the consent of the Verkhovna Rada of Ukraine on the grounds and in the manner determined by the criminal procedural legislation of Ukraine, and would remove restrictions on investigative actions against deputies. The issue of preventing deputies from leaving the country has not been resolved, regarding which the Verkhovna Rada is considering the issue about giving consent on their prosecution.

At the same time, the level of corruption in executive bodies is decreasing rather slowly. One of the reasons for this situation is incompleteness and fragmentation of administrative reform of central executive bodies (division of powers, deregulation of entrepreneurial activity, simplification of procedures for the provision of administrative services, etc.). The introduction of anti-corruption programs confirmed the absence of personnel and institutional mechanisms for their implementation, as well as the lack of expert capacity for assessing and identifying corruption risks in the activities of state authorities. Therefore, it is extremely important to increase the effectiveness of the implementation of anti-corruption programs. An important task in implementing the reform of the civil service remains the reduction of corruption-related risks and increase of level of good faith in the civil servants' behavior.

As the analysis of statistical data of the Ministry of Internal Affairs of Ukraine has shown, at the present stage there is a gradual decrease in the number of registered corruption offences and an increase in the indicators of bringing officials to responsibility (including criminal one). Thus, during 9 months of 2017, 4481 reports on corruption offences were sent to

\footnotetext{
${ }^{8}$ Антикорупційна стратегія на 2018-2020 роки: проект [Електронний ресурс]. - Режим доступу: http://nazk.gov.ua/uk/
} 
the court (in the corresponding reporting period of 2016 -5022), 2295 of them are criminal offences, 2265 cases were sent to court with the indictment (in the corresponding period of $2016-1576$ ). As a result of their consideration, 2,400 civil servants were prosecuted (in the corresponding period of 2016 - 1700).

Based on the given above, one can confidently state that corruption in Ukraine primarily creates a threat to financial stability, because it does not counteract to the formal economy, but exists in it, and acts as a natural and logical consequence of the legal status of economic and management entities. It appears that the officials of certain state structures not only serve the economy, they take part in it, having "their share" in the economy. It is the functioning of the state-political machine that is economically dependent, so it is subordinated, in the essence, to the economic consciousness. Thus, despite the general decrease in the number of registered corruption offences and the increase in the indicators of bringing persons to liability, the total number of corrupt acts and the resulting material losses remains rather high, as well as the level of perception of corruption phenomena by the population.

The counteraction to corruption is based on three components: 1) the presence of political will of the state management; 2) the formation of a negative attitude towards corruption among population; 3) elimination/ maximum reduction of conditions and incentives for corruption; 4) effective detection of corruption offences, inevitability of punishment for their commission. All of the above elements should be reflected in the state policy of Ukraine in the field of corruption prevention. Therefore, the problem of analyzing and improving the direction of the state policy of Ukraine in the field of corruption prevention remains relevant.

Today, it is rather difficult to determine the real extent of corruption and the effectiveness of measures aimed at fighting against it, and therefore, it is reasonable to carry out an assessment not according to individual criteria, but on a combination of factors, in particular, based on: 1) statistical data (they are important for state bodies, including law enforcement), 2) the rating level defined by international organizations (for example, Transparency International); 3) the population's attitude to this process (is the most optimal criterion for the efficiency of the authorities' work in this field). 


\section{Corruption Offences and Ways of Counteraction}

In the modern period, despite the active discourse in the circles of theorists and practitioners, there are many problematic issues, first of all, with the definition of the concept of corruption offence and liability for them. In this regard, it is reasonable to determine what exactly should be understood under the corruption-related crimes in the understanding of Ukrainian lawmaker and in the light of international experience on the given issue.

Certain provisions of the UN Convention against Transnational Organized Crime are devoted to the definition of corruption crimes. In particular, Article 8 "Criminalization of corruption" of the United Nations Convention against Transnational Organized Crime of November 15, 2000 (ratified by Ukraine with limitations and statements on February 4, 2004) indicates the need to recognize such acts as criminal offences when committed intentionally: a) the promise, offering or giving to a public official, directly or indirectly, of an undue advantage, for the official himself/herself or another person or entity, in order that the official act or refrain from acting in the exercise of their official duties; b) the solicitation or acceptance by a public official, directly or indirectly, of an undue advantage for the official himself/herself or another person or entity, in order that the official act or refrain from acting in the exercise of their official duties. This Convention also provides that each State Party shall consider the possibility of criminalizing: 1) the cases referred to above if any foreign public official or international civil servant is involved; 2) participation as an accomplice in the commission of any crime recognized in accordance with Article 8 of this Convention; 3) any other forms of corruption.

The Criminal Law Convention on Corruption (ETS 173), adopted on 27 January, 1999 in Strasbourg and ratified by Ukraine on October 18, 2006 recalls about corruption-related crimes, or rather, "crimes related to corruption", in the light of the official translation into Ukrainian. The Civil Convention on corruption (ETS 174), adopted on November 4, 1999 in Strasbourg and ratified by Ukraine on March 16, 2005 refers to "corruption actions". The UN Convention against Corruption on October 31, 2003 (ratified by Ukraine with statements on October 18, 2006) also refers to "crimes recognized (specified) by this Convention". This convention is based on a number of other important international legal instruments on the prevention and counteraction of corruption (in 
particular, the Inter-American Convention against Corruption, adopted by the Organization of American States on March 29, 1996; The Convention against corruption affecting public officials of the European Communities or public officials of the Member States of the European Union, adopted by the Council of the European Union on May 26, 1997; Convention against Bribery of Foreign Public Officials in international business transactions, adopted by the Organization for Economic Co-operation and Development on November 21, 1997; Criminal Law Convention on Corruption, adopted by the Committee of Ministers of the Council of Europe on January 27, 1999; Civil Convention against corruption, adopted by the Committee of Ministers of the Council of Europe on November 4, 1999; The African Union Convention on the Prevention and Fighting of Corruption, adopted by the Heads of State and Government of the African Union on 12 July 2003; UN Convention against Transnational Organized Crime of November 15, 2000).

A typical aspect of Ukrainian criminal law is the lack of a systematic approach to understanding of corruption-related crimes and responsibility for them. In particular, Article 1 "Definition of Terms" of the Law of Ukraine "On Prevention of Corruption" on October 14, 2014 states that corruption is the use by a person specified in Part 1 of Article 3 of this Law, the official powers granted to him/her or the related opportunities for the purpose of obtaining an unlawful benefit or the acceptance of such benefit or the acceptance of promise/offer of such benefit for himself/herself or other persons or, accordingly, the promise/offer or provision of unlawful benefit to the person specified in Part 1 Article 3 of this Law, or upon his/her request to other natural or legal persons, in order to incline the person to the unlawful use of the official powers granted to him/her or the related opportunities. The specified Law distinguishes between two types of corruption offences: corruption offences and corruption-related offences.

The Criminal Code of Ukraine does not contain a fixed definition and a separate section in which all the existing compositions of corruption crimes are grouped. Existing practice is completely justified in view of the tradition of forming the structure of the Criminal Code of Ukraine and the spread of corruption manifestations in almost all fields of society daily life. The concept of a corruption crime of the Criminal Code of Ukraine reveals its content through listing all the acts that may be attributed to corruption in Article 45 of the Criminal Code of Ukraine. Thus, the note to this article under corruption crimes means crimes envisaged by 
Articles 191, 262, 308, 312, 313, 320, 357, 410 of the Criminal Code of Ukraine, in the case of their commission by abuse of official powers, as well as crimes provided by Articles 210, $354,364,364-1,365-2,368$ 369-2 of the Criminal Code of Ukraine.

Thus, the range of corruption crimes is divided into 2 groups by a lawmaker. The first group includes: appropriation, embezzlement or acquisition of property by abuse of official powers (Article 191 of the Criminal Code of Ukraine); theft, appropriation, extortion of firearms, ammunition, explosives or radioactive materials or their acquisition by fraud or abuse of official powers (Article 262 of the Criminal Code of Ukraine); theft, appropriation, extortion of narcotic drugs, psychotropic substances or their analogues or their acquisition by fraud or abuse of official powers (Article 308 of the Criminal Code of Ukraine); theft, appropriation, extortion of precursors or their acquisition by fraud or abuse of official powers (Article 312 of the Criminal Code of Ukraine); theft, appropriation, extortion of equipment intended for the manufacture of narcotic drugs, psychotropic substances or their analogues, or their acquisition by means of fraud or abuse of official powers and other unlawful actions with such equipment (Article 313 of the Criminal Code of Ukraine); violation of established rules of circulation of narcotic drugs, psychotropic substances, their analogues or precursors (Article 320 of the Criminal Code of Ukraine); theft, appropriation, extortion of documents, stamps, seals, their acquisition by means of fraud or abuse of official powers or their damage (Article 357 of the Criminal Code of Ukraine); theft, appropriation, extortion by a serviceman of weapons, ammunition, explosives or other combat substances, means of transport, military and special equipment or other military property, as well as their acquisition by means of fraud or abuse of official powers (Article 410 of the Criminal Code of Ukraine). These acts, which in their "pure" form do not constitute corruption, but can be attributed to such actions only in view of their commission by certain categories of persons, determined at the level of Part 3, 4 of Article 18 of the Criminal Code of Ukraine and in the notes to Article 364 of the Criminal Code of Ukraine.

The second group is already the actual corruption crimes themselves, which exclusively contain the unlawful corruption component: misuse of budget funds, budget expenditures or granting of credits from the budget without established budget allocations or with their excess (Article 210 of the Criminal Code of Ukraine); bribing an employee of an enterprise, institution or organization (Article 354 of the Criminal Code of Ukraine); 
abuse of power or official position (Article 364 of the Criminal Code of Ukraine); abuse of power by an official of a legal entity of private law irrespective of the organizational and legal form (Article 364-1 of the Criminal Code of Ukraine); abuse of power by persons providing public services (Article 365-2 of the Criminal Code of Ukraine); acceptance of a proposal, promise or obtaining an unlawful benefit by an official (Article 368 of the Criminal Code of Ukraine); illegal enrichment (Article 368-2 of the Criminal Code of Ukraine); bribery of an official of a legal entity of private law irrespective of the organizational and legal form (Article 368-3 of the Criminal Code of Ukraine); bribery of the person providing public services (Article 368-4 of the Criminal Code of Ukraine); a proposal, a promise or an unlawful benefit to an official (Article 369 of the Criminal Code of Ukraine); abuse of influence (Article 369-2 of the Criminal Code of Ukraine) ${ }^{9}$.

According to some researchers, the lack of a single generalized concept of "corruption crime" is a legitimate step, taking into account the impossibility of adapting and extending a certain interpretation of such concept to a limited range of corruption acts. Researchers point out that it is impossible to develop a generalized legal structure to such extent that would reflect absolutely all manifestations (signs) of corruption, and therefore the application of such approach, original to a certain extent, to distinguishing acts that are corruptive is absolutely logical ${ }^{10}$. Moreover, it is reasonable to support the idea that at the present stage the tendency of changing philological (grammatical) interpretation of the corruption concept becomes noticeable, because its understanding (from the Latin corrumpere - "deprave") begins to prevail as disintegration, depravity, etc., not as bribery, corruption as it was ${ }^{11}$. One began to include in corruption such acts that violate the established procedure for the implementation of financial transactions (financial activities) or so-called financial law order, which determines the conduct of various types of economic activity.

\footnotetext{
${ }^{9}$ Кримінальний кодекс України : Закон України від 5 квітня 2001 року № 2341-III [Електронний pecypc]. - Режим доступу : http://zakon4.rada.gov.ua/laws/show/2341-14.

${ }^{10}$ Кримінальна відповідальність за корупційні правопорушення [Електронний ресурс]. - Режим доступу: http://jurblog.com.ua/2017/06/kriminalna-vidpovidalnist-za-koruptsiyni-pravoporushennya/.

11 Стрельцов Є.Л. Еволюція у розумінні корупції: зміна акцентів / Соціальна функція кримінального права: проблеми наукового забезпечення, законотвоення та правозастосування : матеріали міжнар. наук.-практ. конф., 12-13 жовт. 2016 р. / редкол.: В. Я. Тацій (голов. ред.), В. І. Борисов, (заст. голов. ред.) та ін. - Х. : Право, 2016. - 564 с. С. $65-70$.
} 
Legislative provisions on the fight against corruption crimes are sufficiently unbalanced, and, on the contrary, decriminalization of many acts has taken place under the idea of strengthening the fight against corruption. Thus, excess of authority is unjustly decriminalized, committed by an official who is not a law enforcement official (Article 365 of the Criminal Code of Ukraine). As a result, the courts and authorities of the pre-trial investigation are forced either not to bring to justice the persons who commit acts of significant social danger or to "adjust" unlawfully the qualification of the committed act to abuse of power or official position (Article 364 of the Criminal Code of Ukraine), although it is known there is an essential difference that between excess and abuse ${ }^{12}$.

On the other hand, the qualitative filling of the list of corruption crimes can still be put in doubt. In particular, certain acts belonging to the first group of corruption offences (acts stipulated in Articles 262, 308, $312,313,320,410$ of the Criminal Code of Ukraine) are not included in existing international legal acts as such. However, some authors emphasize that "the consolidation of the list of corruption crimes in the law on criminal liability was primarily aimed at preventing or complicating the application of preferential (incentive) norms of criminal law to those who committed such acts (in particular, the institute of exemption from criminal liability, the appointment more lenient punishment than prescribed by law, exemption from punishment with trial or serve sentence by amnesty, removal of conviction, etc.)" ${ }^{\prime 13}$.

This state of affairs in the current criminal law is explained by the "plateau effect", in which there is a national criminal law doctrine, and due to which the latter does not develop a criminal law with the necessary effectiveness coefficient necessary for an ordinary person and expected by society $^{14}$. It is worth mentioning that initially the legislative definition of corruption crimes in the National Criminal Code appeared on the basis of

12 Пономаренко Ю.А. Деякі перспективи розвитку кримінально-правової політики України на основі Доської Декларації 2015 року / Соціальна функція кримінального права: проблеми наукового забезпечення, законотворення та правозастосування : матеріали міжнар. наук.-практ. конф., 12-13 жовт. 2016 р. / редкол.: В. Я. Тацій (голов. ред.), В. І. Борисов, (заст. голов. ред.) та ін. - Х. : Право, 2016. 564 c. - C. $142-146$.

${ }^{13}$ Тютюгін В. І. Поняття та ознаки корупційних злочинів / В. І. Тютюгін, К. С. Косінова // Вісник Асоціації кримінального права України. - 2015. - № 1(4). - С. 391-392.

14 Савінова Н.А. Ефект плато (plateau effect) у парадигмі вітчизняної кримінально-правової доктрини / Соціальна функція кримінального права: пролеми наукового забезпечення, законотворення та правозастосування : маеріали міжнар. наук.-практ. конф., 12-13 жовт. 2016 р. / редкол.: В. Я. Тацій (голов. ред.), В. І. Борисов, (заст. голов. ред.) та ін. - Х. : Право, 2016. - 564 с. - С. 119-124. 
the Law of Ukraine "On the National Anti-Corruption Bureau of Ukraine" on October $14,2014,{ }^{15}$ which supplemented Article 45 of the Criminal Code of Ukraine, containing a list of corruption crimes. However, later on, the version of the said note was revised by law and on the basis of the Law of Ukraine "On Amendments to Certain Legislative Acts of Ukraine on Ensuring the Activities of the National Anti-Corruption Bureau of Ukraine and the National Agency for the Prevention of Corruption" on February 12, 2015, the note to the Article 45 of the Criminal Code of Ukraine received a current version ${ }^{16}$. According to the above norm, the legislative definition of corruption offences is given not in the context of their broad description with the disclosure of specific features, but by the listing of specific articles of the Criminal Code of Ukraine, establishing liability for such socially dangerous infringements, that is, the lawmaker gave their complete list.

It should be emphasized that in theory and in practice, there are also many disputable (problematic, controversial) issues regarding criminal liability and punishment for corruption crimes that require a fundamental solution. It is difficult to make an exhaustive list of such issues (for example, what is the relation between the terms "civil servant" " and "official", what specifically contains the terms "acceptance of a proposal" and "acceptance of promise"; whether the term "expression" is not narrow in clause 3 of the note to Article 354 of the Criminal Code of Ukraine and whether it would be worthy to replace it with a phrase "a notification in any way"; whether a promise of unlawful profit is possible if the intention is announced with a notification about time and place, but not on the method; what is the content of the structure of "any other benefits of nonmaterial or non-monetary nature", etc. $)^{17}$.

Absolutely effective prevention and counteraction to corruption is an objective necessity for the further positive development of Ukraine as a law-governed, democratic and social state. Meanwhile, despite the considerable amount of scientific research and legislative acts, active and loud statements made by government officials, it should be noted that

\footnotetext{
15 Про Національне антикорупційне бюро України: Закон України від 14 жовтня 2014 року № 1698-VII [Електронний ресурс]. - Режим доступу : http://zakon4.rada.gov.ua/laws/show/1698-18/page.

16 Про внесення змін до деяких законодавчих актів України щодо забезпечення діяльності Національного антикорупційного бюро України та Національного агентства з питань запобі- гання корупції : Закон України від 12 лютого 2015 року № 198-VIII [Електронний ресурс]. - Режим доступу : http://zakon4.rada.gov.ua/laws/show/198-19/paran27\#n27.

17 Савченко А. В. Корупційні злочини (кримінально-правова характеристика) навч. посіб. / А. В. Савченко - К. : «Центр учбової літератури», 2016. - 168 с.
} 
today, in fact, there are no significant results, and the state of the fight against corruption remains to be unsatisfactory.

The search for specific reasons for the existence of corruption in each individual society is determined to be defeated in advance. However, it is reasonable to support the opinion of Professor O. M. Kostenko, who emphasizes that present corruption in Ukraine is a crisis-type corruption; it is a product of a deep social crisis in Ukraine. "Such corruption has the ability to bring to nothing any reforms in the country, and also causes the alienation of Ukraine in the world. The so-called "corruption component" plays a role both in what happened in Crimea and in today's situation in the East of Ukraine: if Ukrainian society had not suffered from corruption, then everything could have been different. Therefore, corruption is a political problem number one for Ukraine"18.

The complexity of counteracting to corruption at the present stage is in the prevalence of the second of two basic types of corruption, with the following names proposed: 1) "Roman type" (to pay for obtaining the excessive or forbidden); 2) "Byzantine type" (to pay for obtaining the proper, guaranteed by laws) ${ }^{19}$.

There is no point in idealizing and pointing out on the fact that economically and socially developed countries do not have corruption. Scandals about its first, that is, Roman type at the level of deputy minister, periodically appear in many countries in Europe and America. However, in the case of Byzantine type, in all developed countries, there are positive results in counteracting to such manifestations. That is why their disapproval is clear to those undeveloped subjects of international law, where corruption of the second (Byzantine) type (Ukraine, Cameroon, Iran, Nepal, Nicaragua, Paraguay, etc.) is not overcome. In connection with this, the urgent need of Ukrainian society today is the real destruction of the basis of "Byzantine" type ${ }^{20}$ of corruption and the development of effective levers for counteraction to Roman-type corruption.

In connection with the above, it is reasonable to support the opinion of Professor O. M. Kostenko, who points out that a truly effective anticorruption policy in Ukraine could be a policy based on the concept of

\footnotetext{
${ }^{18}$ Костенко О.М. Корупція в Україні - це наслідок соціальної аномалії [Електронний ресурс]. Режим доступу: http://slovoprosvity.org/2017/08/24/koruptsiya-v-ukrajini-tse-naslidok-sotsialnoji-anomaliji/.

19 Gorky Look. Сорта «того-самого», або Каррумба! (парт оне). Коррумба, або Дай сюда, иди отсюда (парт тво) // [Електронний ресурс]- Режим доступу : http://gorky-look. livejournal.com/71734.html.

${ }^{20}$ Радутний О.Е. - інформаційний образ ворога у кримінальному праві України [Електронний pecypc] - Режим доступу : http://ippi.org.ua/sites/default/files/13_2.pdf.
} 
"anti-corruption clutches", confirmed by experience, for example, in Singapore. In particular, such policy is to combine the two "bites" into "anti-corruption clutches": the first one is deep social reforms that have anticorruption potential, and the second one is the use of repressive measures against corrupt officials to be used by anti-corruption bodies ${ }^{21}$.

Attempts to overcome the crisis type of corruption only by improving the anti-corruption legislation and anti-corruption bodies are hopeless. "It is impossible to create such a law or an anti-corruption body, which could not be abused if there is a social anomaly in a society in which to live and work honestly and lawfully is not beneficial. Moreover, it is possible to form the so-called "police state" under this condition. In the result of social reforms Ukraine should become a country suitable for the lives of honest and law-abiding citizens. Only then, according to the concept of "anti-corruption clutches", the anti-corruption legislation and any anticorruption authorities, along with civil society institutions can be effective",22.

\section{CONCLUSIONS}

Summarizing the results of the special literature and the current legislation analysis, it is worth pointing out that corruption is currently threatening the ideals of democracy, human rights and the law order in general, destroying proper management, good faith and social justice, impeding competition and economic development of our state, undermining the moral principles of society. Moreover, corruption is closely linked to other forms of crime, including organized crime and economic crime. Corruption also covers enormous amounts of assets that can constitute a significant share of public resources and endangers political stability, sustainable development of the state, its national security, including critical infrastructure objects.

Undoubtedly, the Ukrainian state is able to gradually change the current situation by increasing the public disapproval of corrupt officials, creating anti-corruption bodies, updating anti-corruption legislation, appearing of a corruption exposing movement, etc. So, according to sociological surveys, in 2014, only $13 \%$ of Ukrainian citizens were ready

\footnotetext{
${ }^{21}$ Костенко О.М. Причина української корупції - аномальний стан суспільства, за якого жити чесно - невигідно [Електронний ресурс]. - Режим доступу: http://nikorupciji.org/2017/03/16/prychynaukrajinskoji-koruptsiji-anomalnyj-stan-suspilstva-za-yakoho-zhyty-chesno-nevyhidno/.

22 Костенко О.М. Причина української корупції- аномальний стан суспільства, за якого жити чесно - невигідно [Електронний ресурс]. - Режим доступу: http://nikorupciji.org/2017/03/16/prychynaukrajinskoji-koruptsiji-anomalnyj-stan-suspilstva-za-yakoho-zhyty-chesno-nevyhidno/.
} 
to report on known cases of corruption. In 2015, Transparency International conducted an information campaign "They would not be silent", which allowed seeing city lights in different cities calling for not to keep silent about corruption for several months. As a result of this campaign - there were three times more accusers of corruption. Today, $45 \%$ of Ukrainians declare their willingness to talk about cases of corruption known to them. At the same time, only $2 \%$ of informants appeal to law enforcement agencies about corruption facts known to them.

Nevertheless, despite all the positive developments, Ukraine remains at one level in relation to the anticorruption index with Iran, Cameroon, Nepal, Nicaragua and Paraguay. The conducted sociological surveys show that today more than half of population of our state is inclined to commit corruption offences in case it can contribute to solving the problem. In addition, a significant share of the population, taking into account the lack of relevant knowledge, does not classify certain behaviors as corrupt, while recognizing the non-compliance of such behavior with the norms of morality or professional ethics.

Another reason for the slow overcoming of corruption is such state of the society in which to live and work honestly is unprofitable, and vice versa, it is profitable to live and work only dishonestly. In this regard, it is worth emphasizing on the fact that, according to the United Nations, Ukraine is at a level of salary somewhere between Nigeria and Mongolia, and more than $80 \%$ of Ukrainians are over the limit of poverty (in poor countries in Africa the poverty line is $\$ 1.25$ US per day, in Ukraine $-\$ 1.5)^{23}$.

However, the main factors explaining the spread of corruption in Ukraine are not only extremely low incomes but also many other things: the absence of a negative attitude to corruption among the population, inadequate and economically unreasonable salaries of civil servants and persons equated to them, a delay in real punishment of corrupt officials, an increase in the corrupt component in the relations between business and government, the ineffectiveness of the bodies that identify, prevent and fight with corruption, ignoring the results of science of new research on preventing and counteracting to corruption, national anti-corruption legislation gaps and so on. Among the listed above, a special attention should be paid to a scientific and normative component in counteracting to corruption manifestations, in particular, in view of theoretical

\footnotetext{
${ }^{23} 80$ відсотків населення України живе за межею бідності - ООН [Електронний ресурс]. - Режим доступу : http://www.radiosvoboda.org/content/article/26959841.html.
} 
developments in the field of criminal law and relevant articles of the Criminal Code of Ukraine.

In view of the above, it is worth noting that the formation of a legislative and institutional framework for the development and implementation of state anti-corruption policy in Ukraine has not been fully completed, in particular, there have been conflicts between the relevant legislative acts regarding the powers of the anti-corruption bodies and their proper cooperation, and no steps have been taken to eliminate them immediately; further harmonization of national legislation with international treaties and the practice of their application is necessary. Certainly, overcoming corruption is closely linked with the development of a new Ukraine - a country without social anomalies, which will be based on such a social order, in which the norm of social life of people is honesty and legal culture. Without these factors, the progress (political, economic, legal, moral) and the effective process of corruption counteraction can not be implemented in the country.

That is why today it is absolutely necessary to continue the formation of a negative attitude towards corruption among the population, because without anti-corruption morality, any anti-corruption legislation is a "paper tiger". According to this conception, the formula for counteraction of corruption should be as follows: "the formation of anti-corruption morality in society plus the application of anti-corruption legislation". One without the other is like scissors with one blade, if the second is broken. In this regard, it is worth mentioning Thomas Carlyle's idea: "Any reforms, except moral, are useless" 24 .

\section{SUMMARY}

The article mentions that corruption can counteract to the effective development of the state economy and civil society, being at the stage of formation. It is one of the main causes of political and social instability in Ukraine.

Corruption has a devastating impact on all domains of life of Ukrainian society, and it is a serious obstacle to economic reforms, it impedes the formation of market institutions, prevents from investment and threatens Ukrainian national security, including critical infrastructure onjects.

\footnotetext{
${ }^{24}$ Костенко О.М. Причина української корупції - аномальний стан суспільства, за якого жити чесно - невигідно [Електронний ресурс]. - Режим доступу: http://nikorupciji.org/2017/03/16/prychynaukrajinskoji-koruptsiji-anomalnyj-stan-suspilstva-za-yakoho-zhyty-chesno-nevyhidno/.
} 
At the same time, corruption has a nationwide systemic nature and influences Ukrainian politics, economics and other domains of public life significantly. High cost of living and a low level of legal and political culture in Ukraine predetermine the spread of corruption as a social phenomenon. It is the most essential reason for decreasing in the level of public trust to all public authorities.

\section{REFERENCE}

1. Рудь I. Закон про кібербезпеку: основні положення, оцінки експертів та розвиток вітчизняного інформаційного простору [Електронний ресурс] / I. Рудь // Україна: події, факти, коментарі. 2017. - № 19. - С. 42-48. - Режим доступу: http://nbuviap.gov.ua/ images/ukraine/2017/ukr19.pdf.

2. Фонд «Демократичні ініціативи» [Електронний ресурс]Режим доступу : http://dif.org.ua/category/opinion-polls.

3. ЄС виділяє 16 мільйонів євро на боротьбу 3 корупцією в Україні / Економічна правда // [Електронний ресурс]- Режим доступу : http://www.epravda.com. ua/news/2016/09/16/605743/.

4. ЄС і Данія виділили €16 млн на боротьбу 3 корупцією в Україні. - Режим доступу : http://ukr.lb.ua/news/ 2016/09/15/345242_ ies_i_daniya_vidilili_16_mln_borotbu.html.

5. Засади державної антикорупційної політики в Україні (Антикорупційна стратегія) на 2014-2017 роки, затв. Законом України від 14 жовтня 2014 року № 1699-VII [Електронний ресурс]. - Режим доступу: http://zakon2.rada.gov.ua/ laws/show/1699-18.

6. Національна антикорупційна стратегія на 2011-2015 роки, затв. Указом Президента України від 21 жовтня 2011 року № 1001/2011 [Електронний ресурс]. - Режим доступу: http://zakon2.rada.gov.ua/ laws/show/1001/2011.

7. Антикорупційна стратегія на 2018-2020 роки: проект [Електронний ресурс]. - Режим доступу: http://nazk.gov.ua/uk

8. Кримінальний кодекс України : Закон України від 5 квітня 2001 року № 2341-III [Електронний ресурс].- Режим доступу : http://zakon4.rada.gov.ua/laws/show/2341-14.

9. Кримінальна відповідальність за корупційні правопорушення [Електронний ресурс]. - Режим доступу: http://jurblog.com.ua/ 2017/06/kriminalna-vidpovidalnist-za-koruptsiyni-pravoporushennya/.

10. Стрельцов Є.Л. Еволюція у розумінні корупції: зміна акцентів / Соціальна функція кримінального права: проблеми 
наукового забезпечення, законотвоення та правозастосування : матеріали міжнар. наук.-практ. конф., 12-13 жовт. 2016 р. / редкол.: В. Я. Тацій (голов. ред.), В. І. Борисов, (заст. голов. ред.) та ін. - Х. : Право, 2016. - 564 с. - С. 65-70.

11. Пономаренко Ю.А. Деякі перспективи розвитку кримінальноправової політики України на основі Доської Декларації 2015 року / Соціальна функція кримінального права: проблеми наукового забезпечення, законотворення та правозастосування : матеріали міжнар. наук.-практ. конф., 12-13 жовт. 2016 р. / редкол.: В. Я. Тацій (голов. ред.), В. І. Борисов, (заст. голов. ред.) та ін. - Х. : Право, 2016. - 564 с. - C. 142-146.

12. Тютюгін В. I. Поняття та ознаки корупційних злочинів / В. І. Тютюгін, К. С. Косінова // Вісник Асоціації кримінального права України. - 2015. - № 1(4). - С. 391-392.

13. Савінова Н.А. Ефект плато (plateau effect) у парадигмі вітчизняної кримінально-правової доктрини / Соціальна функція кримінального права: пролеми наукового забезпечення, законотворення та правозастосування : маеріали міжнар. наук.-практ. конф., 12-13 жовт. 2016 р. / редкол.: В. Я. Тацій (голов. ред.), В. І. Борисов, (заст. голов. ред.) та ін. - Х. : Право, 2016. - 564 с. - С. 119-124.

14. Про Національне антикорупційне бюро України: Закон України від 14 жовтня 2014 року № 1698-VII [Електронний pecypc]. - Режим доступу : http://zakon4.rada.gov.ua/laws/show/169818/page.

15. Про внесення змін до деяких законодавчих актів України щодо забезпечення діяльності Національного антикорупційного бюро України та Національного агентства 3 питань запобі- гання корупції : Закон України від 12 лютого 2015 року № 198-VIII [Електронний ресурс]. - Режим доступу : http://zakon4.rada.gov.ua/ laws/show/198-19/paran27\#n27.

16. Савченко А. В. Корупційні злочини (кримінально-правова характеристика) навч. посіб. / А. В. Савченко - К. : «Центр учбової літератури», 2016. - 168 с.

17. Костенко О.М. Корупція в Україні - це наслідок соціальної аномалії [Електронний ресурс].- Режим доступу: http://slovoprosvity.org/2017/08/24/koruptsiya-v-ukrajini-tse-naslidoksotsialnoji-anomaliji/.

18. Gorky Look. Сорта «того-самого», або Каррумба! (парт оне). Коррумба, або Дай сюда, иди отсюда (парт тво) // [Електронний 
pecypc]- Режим доступу : http://gorky-look.livejournal.com/ 71734.html.

19. Радутний О.Е. - інформаційний образ ворога у кримінальному праві України [Електронний ресурс]- Режим доступу : http://ippi.org.ua/sites/default/files/13_2.pdf.

20. Костенко О.М. Причина української корупції - аномальний стан суспільства, за якого жити чесно - невигідно [Електронний pecypc]. - Режим доступу: http://nikorupciji.org/2017/03/16/prychynaukrajinskoji-koruptsiji-anomalnyj-stan-suspilstva-za-yakoho-zhytychesno-nevyhidno/.

21. 80 відсотків населення України живе за межею бідності- ООН [Електронний ресурс]. - Режим доступу : http://www.radiosvoboda.org/content/article/26959841.html.

Information about the author: Dorokhina Yu. A. Doctor in Law, Assistant Professor, Professor at the Department of Special Legal Disciplines of the Educational-Scientific Humanitarian Institute of the V. I. Vernadsky Taurida National University 